\title{
PENGARUH METODE EKSTRAKSI DAN POLARITAS PELARUT TERHADAP KADAR FENOLIK TOTAL DAUN KERSEN (Muntingia calabura L)
}
(Effect of Extraction Method and Solvent Polarity on Total Phenolic Content of Cherry Leaves (Muntingia calabura L))

\author{
Wina Yulianti ${ }^{1}$, Gilang Ayuningtiyas ${ }^{2}$, Rina Martini ${ }^{3}$, Ika Resmeiliana ${ }^{1}$ \\ ${ }^{1}$ Jurusan Analisis Kimia, Sekolah Vokasi Institut Pertanian Bogor, Jl. Kumbang No.14 \\ Cilibende, Bogor, Indonesia, 16128 \\ 2Jurusan Tenoklogi Manajemen Produksi Ternak, Sekolah Vokasi Institut Pertanian \\ Bogor, Jl. Kumbang No.14 Cilibende, Bogor, Indonesia, 16128 \\ ${ }^{3} J u r u s a n$ Manajemen Industri Jasa Makanan dan Gizi, Sekolah Vokasi Institut Pertanian \\ Bogor, Jl. Kumbang No.14 Cilibende, Bogor, Indonesia, 16128 \\ E-mail : wjuans@apps.ipb.ac.id
}

\begin{abstract}
The method of extraction and the type of solvent used during extraction will influence effectiveness of the extraction and compound extracted. The aim of this research was determined the effect of extraction methode and solvent polarity on total phenolic content of cherry leaves (Muntingia calabura L). Extraction of cherry leaves used maceration and soxhelation methods with ethanol and chloroform as solvents. The total phenolic contain was determined by visible spechtrophotometer at $765 \mathrm{~nm}$. It has been showed that the soxhletation method was a higher yield value than the maceration methods with the highest yield value showed by ethanol extract, it was $13,29 \% \mathrm{w} / \mathrm{w}$. otherwise maceration method showed a higher total phenolic contain with the highest total phenolic contain showed by ethanol extract, it was $10,70 \%$ GAE.
\end{abstract}

Key words : maceration, soxhletation, phenol, Muntingia calabura L, visible spectrophotometer 


\section{PENDAHULUAN}

Indonesia merupakan negara tropis yang mempunyai keanekaragaman tanaman. Salah satu tanaman yang tersebar luas di Indonesia adalah tanaman kersen (Muntingia calabura L). M. calabura dikenal di seluruh dunia sebagai Jamaican cherry dan di Indonesia dikenal sebagai kersen atau talok. Pada mulanya kersen berasal dari Filipina dan pada abad ke-19, mulai berkembang biak di Indonesia. Kersen dapat mencapai tinggi 12 meter dan mudah tumbuh rimbun meskipun dalam suhu panas. Kersen dapat dengan mudah ditemukan di sepanjang jalan sebagai penyerap polusi udara.

Berdasarkan Connor (2015) Tanaman mempunyai kemampuan untuk memproduksi metabolit sekunder yang dapat menampilkan aktivitas biologis. Metabolit sekunder dapat bersifat antiinflamasi, antipiretik, antibakteri, antiproliperatif, antioksidan, dan antihipertensi (Thirumurugan et al., 2018). Pada penelitian sebelumnya telah dilaporkan bahwa ekstrak daun kersen (Muntingia calabura L) menunjukkan aktivitas antimikroba (Buhian et al., 2016; Gurning et al., 2021; Surjowardojo et al., 2014), antibakteri (Simamora et al., 2020; Juariah et al., 2020) antioksidan (Pamungkas et al., 2016; Kumar et al., 2020; Prayitno \& Rahim, 2020) antidiabetes (Syahara et al., 2019); dan berpotensi untuk menurunkan kadar kolesterol (Putri, et al., 2018)

Daun kersen memiliki kandungan metabolit sekunder antara lain: tanin, sterols, alkaloid, saponin, flavonoid, dan glikosida (Krishnaveni and Dhanalakshmi, 2014); alkaloid, flavonoid, tanin, saponin, dan steroid/terpenoid (Pamungkas, Anam and Kusrini, 2016) saponin dan alkaloid (Putri et al., 2018). Analisis fitokimia secara kuantitatif menunjukkan bahwa ekstrak daun kersen mengandung kadar tanin $0.0655 \pm 0.0002 \mathrm{mg} / \mathrm{g}$.(Gurning et al., 2021).Total flavonoid dan total fenol $8.96 \pm 0.21 \mathrm{mg} \mathrm{QE} / \mathrm{g}$ dan 0,24 \% GAE (Khan et al., 2018)

Kandungan metabolit yang terkandung pada ekstrak tanaman sangat dipengaruhi oleh metode dan kepolaran pelarut yang digunakan saat ekstraksi. Variasi kepolaran pelarut akan mempengaruhi jumlah ekstrak yang dihasilkan, komposisi fitokimia dan uji aktivitasnya (Buhian et al., 2016). Metode maserasi ekstrak daun jati belanda menunjukkan kadar fenolik dan flavonoid lebih tinggi dibandingkan dengan metode perebusan (Nuri et al., 2020). Metode ekstraksi dan kepolaran pelarut pada saat ekstraksi menunjukan perbedaan kandungan total fenolik yang sangat signifikan (Hayouni et al., 2007; Bucić-Kojić et al., 2011; Scherer \& Godoy, 2014)

Senyawa fenolik adalah senyawa yang banyak ditemukan pada tumbuhan. Senyawa ini telah diketahui strukturnya, diantaranya adalah kuinon fenolik, flavonoid, fenil propanoid, fenol monosiklik sederhana, polifenol (tannin, lignin melanin), dan kuinon fenolik. Senyawa fenolik dilaporkan memiliki sifat antioksidan (Marjoni \& Afrinaldi, 2015; Pamungkas et al., 2016)

Pada penelitian in bertujuan untuk mengetahui pengaruh perbedaan metode ekstraksi dan polaritas pelarut terhadap kadar fenolik total pada daun kersen. Ekstraksi dilakukan dengan metode maserasi dan sokletasi dan pelarut yang 
digunakan adalah etanol dan kloroform. Kadar fenolik total dianalisis secara spektrofotometri.

\section{METODE PENELITIAN}

\section{Alat dan Bahan}

Alat yang digunakan pada penelitian ini adalah peralatan gelas, neraca analitik, kondensor, labu bulat, labu soklet, blender, rotary evaporator EYELA, spektrofotometer Genesis 30, oven. Bahan yang digunakan adalah daun kersen, etanol pa, kloroform pa, kertas saring, aquades, asam galat, pereaksi folin Ciocalteu, natrium karbonat,

Preparasi Sampel (Neto et al., 2013)

Daun kersen diperoleh dari tanaman kersen yang berada di sekitaran kampus sekolah Vokasi IPB Bogor pada bulan November 2021. Sampel terlebih dahulu dikeringudarakan tanpa kena sinar matahari secara langsung selama 24 jam. Daun yang sudah dikeringudarakan kemudian dioven pada suhu $40^{\circ} \mathrm{C}$ selama $3 \times 24$ jam. Daun kersen yang sudah dioven kemudian dihaluskan menggunakan blender. Sampel yang sudah diblender digunakan untuk tahapan analisis selanjutnya.

Ekstraksi sampel (Neto et al., 2013)

Daun kersen masing-masing ditimbang sebanyak 15 gram. Sampel kemudian diekstraksi dengan cara maserasi. dan sokletasi dengan menggunakan pelarut etanol dan kloroform. Rasio perbandingan bobot sampel dan pelarut pengekstrak sebesar 1:20. Proses ekstraksi dilakukan selama $3 \times 24$ jam. Pada proses maserasi, dilakukan proses penyaringan setiap 24 jam. Filtrat yang diperoleh dari hasil penyaringan ditampung kemudian endapan ditambahkan dengan pelarut baru. Ekstrak yang diperoleh dari proses ekstraksi dipekatkan menggunakan rotary evaporator.

\section{Pembuatan Kurva Kalibrasi Asam Galat (Pamungkas et al.,2016)}

Larutan standar asam galat 500 ppm dipipet masing-masing sebanyak $0,5 \mathrm{~mL} ; 2,5 \mathrm{~mL} ; 3,5 \mathrm{~mL}$ dan $5 \mathrm{~mL}$ ke dalam labu takar $25 \mathrm{~mL}$. Masing-masing larutan dipipet $0,2 \mathrm{~mL}$ ditambahkan $15,8 \mathrm{~mL}$ akuades dan $1 \mathrm{~mL}$ reagen folin Ciocalteu lalu dikocok hingga homogen sehingga terbentuk larutan jernih warna kekuningan. Larutan didiamkan selama 8 menit, kemudian ditambahkan larutan $5 \mathrm{~mL} \mathrm{Na}_{2} \mathrm{CO}_{3}$ $20 \%$, kemudian dihomogenkan dan didiamkan dalam ruang gelap selama 30 menit. Standar kemudian diukur serapannya dengan menggunakan Spektrofotometer sinar tampak pada panjang gelombang $765 \mathrm{~nm}$.

Penentuan Kadar Fenol (Pamungkas, Anam and Kusrini, 2016) 
Ekstrak daun kersen 1000 ppm dalam etanol dipipet sebanyak sebanyak 0,2 $\mathrm{mL}$ ditambahkan $15,8 \mathrm{~mL}$ akuades dan $1 \mathrm{~mL}$ reagen folin Ciocalteu lalu dikocok hingga homogen akan Terbentuk larutan jernih warna kekuningan. Larutan didiamkan selama 8 menit, kemudian ditambahkan larutan $\mathrm{Na}_{2} \mathrm{CO}_{3} 20 \%$, kemudian dihomogenkan dan didiamkan dalam ruang gelap selama 30 menit. Sampel kemudian diukur serapannya dengan menggunakan Spektrofotometer sinarr tampak pada panjang gelombang $765 \mathrm{~nm}$.

\section{HASIL DAN PEMBAHASAN}

\section{Ekstraksi}

Ekstraksi adalah proses transfer selektif senyawa diantara dua pelarut yang tidak saling bercampur, umumnya pelarut organik dan pelarut air atau dari padatan ke cairan. Pemilihan metode ekstraksi yang digunakan tergantung pada tekstur dan kandungan air bahan sampel yang diekstraksi dan senyawa yang diisolasi. Persen rendemen ekstraksi menunjukan efektivitas proses ekstraksi. Efektivitas ekstraksi dipengaruhi oleh besarnya luas permukaan yang berinteraksi dengan pelarut, waktu kontak sampel dan pengekstrak, jumlah volume pelarut yang digunakan dan koefesien distribusi (Meloan, 1999)

Penentuan efektivitas ekstraksi daun kersen pada penelitian ini ditentukan dari variabel metode ekstraksi dan pelarut pengekstrak. Metode ekstraksi yang digunakan untuk mengekstrak daun kersen adalah metode maserasi dan sokletasi menggunakan dua pelarut yaitu etanol dan kloroform (Tabel 1)

Tabel 1 Persen rendemen ekstrak daun kersen

\begin{tabular}{lcc}
\hline Metode & Pelarut & Persen rendemen (\%) \\
\hline Maserasi & etanol & 13,29 \\
& kloroform & 11,08 \\
Sokletasi & etanol & 19,00 \\
& kloroform & 14,00 \\
\hline
\end{tabular}

Metode sokletasi menunjukkan nilai rendemen yang lebih besar dibandingkan dengan metode maserasi baik untuk pelarut etanol maupun kloroform. Proses pemanasan pada metode sokletasi akan meningkatkan kelarutan ekstrak pada pelarut sehingga menghasilkan persen rendemen yang lebih besar. Metode sokletasi juga memiliki keunggulan dalam hal penggunaan pelarut yang lebih sedikit dibandingkan dengan metode maserasi.

Pelarut etanol menghasilkan persen rendemen yang lebih besar dibandingkan dengan pelarut kloroform. Etanol merupakan pelarut yang bersifat polar dan merupakan pelarut yang serba guna dan sangat baik digunakan sebagai ekstraksi pendahuluan (Harbone 1987). Pelarut etanol memiliki sifat untuk menembus bahan dinding sel sehingga mampu melakukan difusi sel dan menarik senyawa bioaktif lebih cepat. (Prayitno and Rahim, 2020). Kloroform merupakan pelarut yang bersifat semipolar dan dapat mengekstrak senyawa metabolit yang bersifat semipolar. Hasil yang diperoleh sesuai dengan hasil yang sudah dilakukan 
oleh Senet et. al. $(2017,2018)$ yang melaporkan bahwa buah dan akar kersen yang diekstrak menggunakan pelarut yang bersifat polar menunjukan persen rendeman yang besar.

Sampel sebelum diekstrak terlebih dahulu dicuci kemudian dikeringudarakan tanpa kena sinar matahari secara langsung, kemudian pengeringan dilanjutkan menggunakan oven pada suhu $40{ }^{\circ} \mathrm{C}$. Pencucian bertujuan untuk menghilangkan pengotor yang menempel pada daun. Pengeringan bertujuan untuk menurunkan kadar air yang terkandung dalam sampel. Kadar air yang tinggi dapat menyebabkan sampel cepat rusak dan mudah ditumbuhi jamur. Pengeringan dalam suhu yang terawasi untuk mencegah terjadinya perubahan kimia yang dapat merusak zat aktif dalam sampel. Penghalusan sampel bertujuan untuk memperbesar luas permukaan yang berinteraksi dengan pelarut sehingga proses ekstraksi berlangsung secara optimal dan juga akan mempengaruhi efektivitas ekstraksi.

\section{Total fenolik}

Senyawa fenolik adalah senyawa yang banyak ditemukan pada tumbuhan. Senyawa ini telah diketahui strukturnya, diantaranya adalah kuinon fenolik, flavonoid, fenil propanoid, fenol monosiklik sederhana, polifenol (tannin, lignin melanin), dan kuinon fenolik. Kadar total fenolik ekstrak kersen menggunakan pereaksi Folin Ciocalteu. Senyawa fenolik bereaksi dengan pereaksi Folin Ciocalteu dalam suasana basa. Ion fenolat akan mereduksi fosfomolibdat fosfotungstat menjadi molybdenum tungsten yang berwarna biru. Asam galat digunakan sebagai larutan standar karena asam galat merupakan senyawa yang murni dan stabil. Semua senyawa fenolik termasuk fenol sederhana dapat bereaksi dengan reagen Folin Ciocalteu. Standar asam galat dengan konsentrasi 0,$08 ; 0,24 ; 0,4 ; 0,56 ; 0,80$ ppm ditentukan serapannya menggunakan spektrofotometer sinar tampak pada panjang gelombang $765 \mathrm{~nm}$ (Tabel 2)

Tabel 2 Absorbansi asam galat dan sampel pada panjang gelombang $765 \mathrm{~nm}$

\begin{tabular}{cc}
\hline Konsentrasi mg/L & Absorbansi \\
\hline 0,08 & 0,01 \\
0,24 & 0,028 \\
0,40 & 0,031 \\
0,56 & 0,050 \\
0,80 & 0,071 \\
\hline
\end{tabular}

Persamaan matematika yang diperoleh dari pengukuran standar adalah $\mathrm{y}=$ $0,0919 x+0,002$ dengan nilai koefesien korelasi $R=0,98$ (Gambar 1). Nilai 0,0919 menyatakan nilai slope yang menandakan sensitivitas pengukuran. Semakin besar nilai slope maka pengukuran semakin sensitif yang artinya perubahan sedikit konsentrasi akan menghasilkan perbedaan serapan yang cukup signifikan. Angka 0,002 adalah intersep, hubungan linier yang ideal ditunjukkan dengan nilai intersep 0 . Nilai korelasi R menggambarkan seberapa kuat hubungan antara dua 
variabel konsentrasi asam galat dengan absorbansinya, Nilai korelasi yang bagus adalah mendekati +1 atau -1 (Riyanto, 2014)

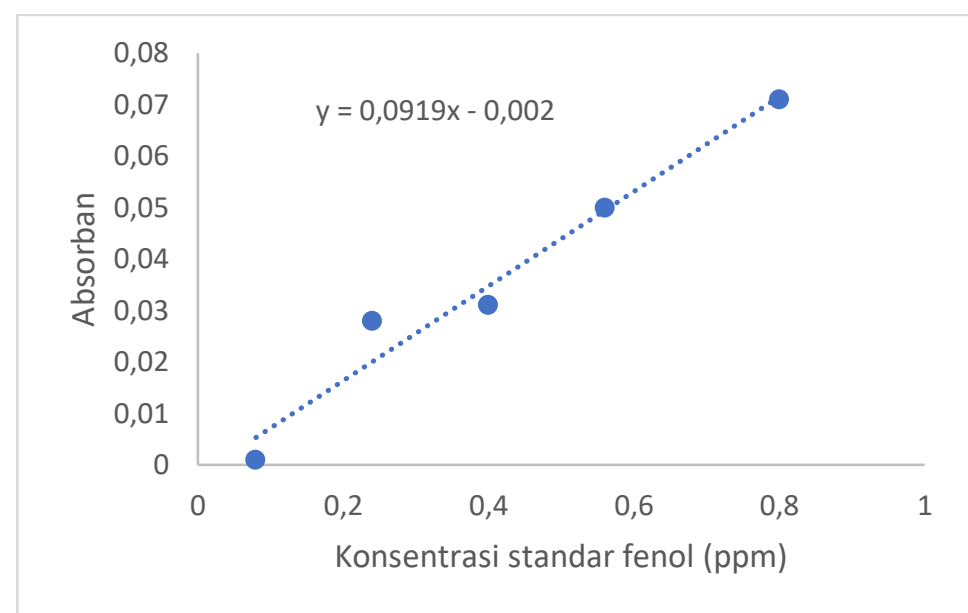

Gambar 1 Kurva standar asam galat

Kadar sampel diperoleh dengan cara menginterpolasi absorban sampel ke dalam persamaan matematika kurva standar. Kadar total asam fenol dinyatakan dalam galat acid equivalen (GAE mg/g sampel) atau (\%GAE b/b). Ekstrak daun kersen yang diekstraksi dengan pelarut etanol menunjukkan kadar fenol yang lebih tinggi dibandingkan pelarut kloroform. Metode ekstraksi daun kersen dengan pelarut etanol menunjukkan kadar fenol yang paling tinggi yaitu 10,70 \% GAE (Tabel 3).

Tabel 3 Total fenol ektrak daun kersen

\begin{tabular}{llcccccccc}
\hline \multirow{2}{*}{ Metode } & Pelarut & \multicolumn{3}{c}{ Absorban } & \multicolumn{4}{c}{ Kadar fenol GAE (ppm) } & Kadar Fenolik \\
& & 1 & 2 & 3 & 1 & 2 & 3 & Rata-Rata & (\%b/b GAE) \\
\hline \multirow{2}{*}{ Maserasi } & etanol & 0,082 & 0,079 & 0,081 & 0,8705 & 0,8379 & 0,8596 & 0,8560 & 10,70 \\
& kloroform & 0,039 & 0,038 & 0,038 & 0,4026 & 0,3917 & 0,3917 & 0,3954 & 4,94 \\
\multirow{3}{*}{ sokletasi } & etanol & 0,051 & 0,05 & 0,052 & 0,5332 & 0,5223 & 0,5441 & 0,5332 & 6,66 \\
& kloroform & 0,041 & 0,041 & 0,038 & 0,4244 & 0,4244 & 0,3917 & 0,4135 & 5,17 \\
\hline
\end{tabular}

Hasil yang diperoleh sesuai dengan penelitian yang telah dilakukan oleh (Phanngam, et.al, 2017) ekstrak metanol akar kersen memiliki kadar total fenolik dan aktivitas antioksidan tertinggi dibandingkan dengan ekstrak yang diperoleh dari pelarut heksana dan etil asetat. Berdasarkan (Nuri et al., 2020) Ekstrak akar kersen dengan pelarut metanol menunjukkan total fenol tertinggi dan menurut (Prayitno and Rahim, 2020) Ekstrak yang diekstraksi dengan pelarut polar menunjukkan total fenol yang lebih tinggi. Dalam proses ekstraksi pemilihan kepolaran pelarut akan menentukan jenis senyawa aktif yang terekstrak (Buhian et. al. 2016). Senyawa yang bersifat polar akan memiliki kecenderungan terekstrak oleh pelarut polar dan sebaliknya senyawa aktif yang bersifat non polar akan terekstrak oleh pelarut non polar. 
Total fenol metode maserasi menunjukan nilai yang lebih tinggi dibandingkan dengan metode sokletasi. Metode maserasi merupakan teknik ekstraksi secara kontinyu tanpa pemanasan, sehingga tidak merusak senyawa aktif yang bersifat tidak tahan panas. Pada metode sokletasi sampel dipanasakan sehingga dapat menyebabkan kerusakan pada komponen aktif yang tidak tahan panas.

\section{SIMPULAN}

Metode sokletasi pada daun kersen menunjukkan nilai rendemen yang lebih besar dibandingkan dengan metode maserasi baik untuk pelarut etanol maupun kloroform. Persen rendemen tertinggi ditunjukkan oleh ekstrak daun kersen pelarut etanol metode sokletasi yaitu $13,29 \% \mathrm{~b} / \mathrm{b}$. Berbeda dengan total fenol, metode maserasi menunjukkan nilai yang tinggi dibandingkan dengan metode sokletasi. Total fenol tertinggi ditunjukan oleh metode maserasi menggunakan pelarut etanol yaitu $10,70 \%$ GAE.

\section{SARAN}

Perlu dilakukan penelitian pengujian aktivitas antioksidan ekstrak daun kersen dan isolasi senyawa aktif yang berpotensi sebagai antioksidan

\section{DAFTAR PUSTAKA}

Bucić-Kojić, A. et al. (2011) 'Effect of extraction conditions on the extractability of phenolic compounds from lyophilised fig fruits (ficus carica I.)', Polish Journal of Food and Nutrition Sciences, 61(3), pp. 195-199. doi: 10.2478/v10222-0110021-9.

Buhian, W. P. C. et al. (2016) 'Bioactive metabolite profiles and antimicrobial activity of ethanolic extracts from Muntingia calabura L. leaves and stems', Asian Pacific Journal of Tropical Biomedicine, 6(8), pp. 682-685. doi: 10.1016/j.apjtb.2016.06.006.

Connor SE. 2015. Engineering of Secondary Metabolism. Annu. Rev. Genet. 2015. 49:5.1-5.24

Gurning, K. et al. (2021) 'Determination of Total Tannins and Antibacterial Activities Ethanol Extraction Seri (Muntingia calabura L.) Leaves', IOP Conference Series: Earth and Environmental Science, 1811(1), pp. 4-9. doi: 10.1088/1742-6596/1811/1/012121.

Hayouni, E. A. et al. (2007) 'The effects of solvents and extraction method on the phenolic contents and biological activities in vitro of Tunisian Quercus coccifera L. and Juniperus phoenicea L. fruit extracts', Food Chemistry, 105(3), pp. 1126-1134. doi: 10.1016/j.foodchem.2007.02.010.

Juariah, S., Yolanda, N. and Surya, A. (2020) 'Efektivitas Ekstrak Etanol Daun Kersen terhadap Staphylococcus Aureus dan Salmonella Typhi', Jurnal Endurance: Kajian IImiah Problema Kesehatan, 5(2), pp. 338-344. 
Khan, M. S. et al. (2018) 'Determination of total phenolic content, total flavonoid content and antioxidant activity of various organic crude extracts of Licuala spinosa leaves from Sabah, Malaysia', ASM Science Journal, 11(Special Issue 3), pp. 53-58.

Krishnaveni, M. and Dhanalakshmi, R. (2014) 'Qualitative and quantitative study of phytochemicals in World Journal of Pharmaceutical Research', World Journal of Pharmaceutical ReseaRch, 3(6), pp. 1687-1696.

Kumar, A. S. et al. (2020) 'Phytochemical screening and in vitro antioxidant study of Magnolia vine, Muntingia calabura, and Alangium salviifolium fruits', International Journal of Green Pharmacy, 14(1), p. 87.

Marjoni M. R. and Afrinaldi, D. N. A. (2015) 'Kandungan Total Fenol Dan Aktivitas Antioksidan Ekstrak Air Daun Kersen (Muntingia calabura L.)', Yarsi medical Journal, 23(32), pp. 187-1962.

Neto B, G. et al. (2013) 'Insecticidal activity of Muntingia calabura extracts against larvae and pupae of diamondback, Plutella xylostella (Lepidoptera, Plutellidae)', Journal of King Saud University - Science, 25(1), pp. 83-89. doi: 10.1016/j.jksus.2012.08.002.

Nuri, N. et al. (2020) 'Pengaruh Metode Ekstraksi terhadap Kadar Fenol dan Flavonoid Total, Aktivitas Antioksidan serta Antilipase Daun Jati Belanda (Guazuma ulmifolia)', Jurnal Sains Farmasi \& Klinis, 7(2), p. 143. doi: 10.25077/jsfk.7.2.143-150.2020.

O'Connor, S. E. (2015) 'Engineering of Secondary Metabolism', Annual Review of Genetics, 49(December), pp. 71-94. doi: 10.1146/annurev-genet-120213092053.

Pamungkas, J. D., Anam, K. and Kusrini, D. (2016) 'Penentuan Total Kadar Fenol dari Daun Kersen Segar, Kering dan Rontok (Muntingia calabura L.) serta Uji Aktivitas Antioksidan dengan Metode DPPH', Jurnal Kimia Sains dan Aplikasi, 19(1), p. 15. doi: 10.14710/jksa.19.1.15-20.

Phanngam, A., Rattana, S. and Sungthong, B. (2017) 'Antioxidant activities, total phenolic and flavonoid contents of Muntingia calabura crude extract', The 13th Mahasarakham University Research Conference, (September 2017), pp. 563-570.

Prayitno, S. A. and Rahim, A. R. (2020) 'The Comparison of Extracts (Ethanol And Aquos Solvents) Muntingia calabura Leaves on Total Phenol, Flavonid And Antioxidant (Ic50) Properties', Kontribusia (Research Dissemination for Community Development), 3(2), p. 319. doi: 10.30587/kontribusia.v3i2.1451.

Putri, C. A., Yuliet and Khaerani, K. (2018) 'EFEKTIVITAS EKSTRAK DAUN KERSEN (Muntingia calabura L.) TERHADAP PENURUNAN KADAR KOLESTEROL TOTAL TIKUS PUTIH JANTAN (Rattus norvegicus L.) YANG DIINDUKSI PAKAN TINGGI LEMAK Cornelia', Biocelebes, 12(1), pp. 65-72.

Riyanto, P. D. (2014) Validasi \& Verifikasi Metode Uji Sesuai dengan ISO/IEC 17025 Laboratorium Pengujian dan Kalibrasi. Yogyakarta: DEEPUBLISH. Available https://play.google.com/books/reader?id=c0mlCgAAQBAJ\&pg=GBS.PA17.

Scherer, R. and Godoy, H. (2014) 'Effects of extraction methods of phenolic compounds from Xanthium strumarium L. and their antioxidant activity', Revista Brasileira de Plantas Medicinais, 16(1), pp. 41-46. doi: 10.1590/s1516-05722014000100006.

Simamora, A. et al. (2020) 'Enzyme inhibitory, antioxidant, and antibacterial activities of ethanol fruit extract of Muntingia calabura Linn', Journal of HerbMed Pharmacology, 9(4), pp. 346-354. doi: 10.34172/jhp.2020.44.

Surjowardojo, P., Thohari, I. S. and Ridhowi, A. (2014) 'Quantitative and Qualitative Phytochemicals Analysis of Muntingia calabura', Journal of 
Biology, Agriculture and Healthcare, 4(16), pp. 84-89.

Syahara, S., Harahap, U. and Widyawati, T. (2019) 'Activity of Muntingia calabura Leaves Ethanolic Extract on Glucose and Insulin Blood Levels in Streptozotocin-induced Rat', Asian Journal of Pharmaceutical Research and Development, 7(4), pp. 8-11. doi: 10.22270/ajprd.v7i4.552.

Thirumurugan, D. et al. (2018) 'An Introductory Chapter: Secondary Metabolites', in Intech. intechopen, pp. 137-144. Available at: https://www.intechopen.com/books/advanced-biometrictechnologies/liveness-detection-in-biometrics. 